\title{
Purification and characterization of a thermostable alkaline cellulase produced by Bacillus licheniformis 380 isolated from compost
}

\author{
ÉVILIN G. DE MARCO ${ }^{1}$, KARINA HECK ${ }^{2}$, EMERSON T. MARTOS ${ }^{3}$, SUELI T. VAN DER SAND ${ }^{1 *}$ \\ ${ }^{1}$ Universidade Federal do Rio Grande do Sul, Programa de Pós-Graduação em Microbiologia \\ Agrícola e do Ambiente, Rua Sarmento Leite, 500, 90050-170 Porto Alegre, RS, Brazil \\ ${ }^{2}$ Universidade Federal de Lavras, Programa de Pós-Graduação em Tecnologias e Inovações \\ Ambientais, Rua Sylvio Menicucci, 1001, 37200-000 Lavras, MG, Brazil \\ ${ }^{3}$ Instituto Superior de Ciências Aplicadas, Rodovia Deputado Laércio Corte, 3000, \\ Chácara Boa Vista da Graminha, 13482-383 Limeira, SP, Brazil
}

Manuscript received on May 28, 2017; accepted for publication on June 28, 2017

\begin{abstract}
During composting processes, the degradation of organic waste is accomplished and driven by a succession of microbial populations exhibiting a broad range of functional competencies. A total of 183 bacteria, isolated from a composting process, were evaluated for cellulase activity at different temperatures (37, 50,60 , and $70^{\circ} \mathrm{C}$ ) and $\mathrm{pH}$ values. Out of the 22 isolates that showed activity, isolate 380 showed the highest cellulase activity. Its ability to produce cellulase was evaluated in culture medium supplemented with carboxymethyl cellulose, microcrystalline cellulose, wheat straw, and rice husk. The culture medium supplemented with carboxymethyl cellulose induced higher enzyme activity after 6 hours of incubation $\left(0.12 \mathrm{UEA} \mathrm{mL}^{-1} \mathrm{~min}^{-1}\right)$. For wheat straw and rice husk, the results were $0.08 \mathrm{UEA} \mathrm{mL}^{-1} \mathrm{~min}^{-1}$ for both, while for microcrystalline cellulose, $0.04 \mathrm{UEA} \mathrm{mL}^{-1} \mathrm{~min}^{-1}$ were observed. The highest carboxymethyl cellulase activity was observed at $60^{\circ} \mathrm{C}\left(0.14 \mathrm{UEA} \mathrm{mL}^{-1} \mathrm{~min}^{-1}\right)$ for both crude and partially purified enzyme after 30 and 120 min of incubation, respectively. Alkalinization of the medium was observed during cultivation in all substrates. The cellulase had a molecular mass of $20 \mathrm{kDa}$ determined by SDS-Page. Isolate 380 was identified as Bacillus licheniformis. This work provides a basis for further studies on composting optimization.
\end{abstract}

Key words: alkalophilic enzyme, carboxymethyl celullase, compost, high temperature.

\section{INTRODUCTION}

Cellulose is considered the most available biomass around the world and a vital, sustainable, and renewable energy source. It is also the most recalcitrant biomass polymer and difficult to degrade. Synthetic enzymes can catalyze the

Correspondence to: Sueli Teresinha Van Der Sand

E-mail: svands@ufrgs.br metabolic conversion of cellulose to glucose; however, research efforts to replace synthetic enzymes by microbial enzyme processes are currently being made to reduce costs and mitigate the industrial and environmental impacts. Pulp products are found in biofuels, biofertilizers, and products of the textile industry (Ladeira et al. 2015, Gaur and Tiwari 2015). 
Plant biomass waste consists almost entirely of lignocellulose, which is formed by three types of polymers, namely cellulose, hemicellulose, and lignin. Cellulose is a linear polymer composed of D-glucose linked by $\beta-1,4$ glucoside bonds (Béguin and Aubert 1994, Lynd et al. 2002). The cellulose enzyme system usually comprises three cellulolytic enzyme classes which hydrolyze the cellulose: endoglucanases (EC 3.2.1.4), cellobiohydrolases (EC 3.2.1.91), and cellobiases (EC 3.2.1.21) (Foster and Whiteman 1992, Rabonovich et al. 2002). These enzymes are widely used to substitute chemical compounds mainly in the pulp and paper industry and in wastewater treatment (Bhat 2000, Acharya and Chaudhary 2012).

Microorganisms are employed directly for bioaugmentation, which is widely used in waste treatment plants (Martin-Ryals et al. 2015). Besides these applications, it is necessary to know the enzymatic capacity of the microorganisms used in any environmental treatment. Cellulases are usually produced by fungi, such as Trichoderma sp., Aspergillus sp. and Lentinula sp. (Bhat 2000, Carvalho et al. 2016), however, these cellulases do not exhibit thermal stability, and environmental induction is necessary for their production. On the other hand, the enzymes produced by bacteria are constitutive (Acharya and Chaudhary 2012). Many species of the genus Bacillus have been studied in terms of the production of thermostable cellulases, such as B. pumilus (Christakopoulos et al. 1999), B. circulans (Waeonukul and Ratanakhanokchai 2007), B. subtilis (Shabeb et al. 2010), B. licheniformis (Acharya and Chaudhary 2012) and B. vallismortis (Gaur and Tiwari 2015).

Composting is a method of waste treatment and comprises organic matter biodegradation mediated by the activities of microbial enzymes. The process occurs under aerobic conditions and through polymer hydrolysis and monomer oxidation, following the use of sugars as a carbon source. Humic and fulvic acids are produced at the end of the process after the mineralization of carbon dioxide. The microbial community profile is defined according to each phase related to increasing or reducing temperatures and the compounds produced in the previous degradation step (Amore et al. 2013). Complex polymers such as proteins, cellulose, lignin, and other recalcitrant molecules are degraded mainly during the thermophilic phase (Sánchez-Monedero et al. 2001), which also contributes to eliminate or decrease pathogenic microorganisms along the composting process (Palmisano and Barlaz 1996, Heck et al. 2013).

The composting process offers an opportunity for the screening of enzymes produced by microorganisms that optimize the biodegradation of recalcitrant organic compounds such as lignocellulosic structures (Lópes-González et al. 2014, Kinet et al. 2015). The aim of this study was therefore to evaluate and characterize the production of carboxymethyl cellulases (endoglucanases) by bacteria isolated from the thermophilic phase of a composting process by applying different carbon sources as substrates in a broad range of temperature and $\mathrm{pH}$ conditions.

\section{MATERIALS AND METHODS}

\section{BACTERIAL ISOLATES}

The bacteria evaluated in this study were isolated from a compost windrow made of organic domestic waste, pruning residue, and sewage sludge from a domestic wastewater treatment plant (Heck et al. 2015). The microorganisms were selected based on their capacity to grow in the thermophilic phase of the composting process; the selection was based on their ability to hydrolyze cellulose using different carbon sources as substrate. 


\section{ENZYME INDEX IN SOLID MEDIUM}

Cellulolytic activity was evaluated using the culture medium proposed by Ramachandra et al. (1987), supplemented with $0.5 \%$ carboxymethyl cellulose (CMC). The isolates were inoculated, using the spot inoculation method, onto plates containing the culture medium and incubated at 37,50 , and $60^{\circ} \mathrm{C}$ for four days and at $70^{\circ} \mathrm{C}$ for three days. After growth, the plates were stained with Lugol solution (1\%) for 3-5 minutes for the visualization of CMC hydrolysis zones (Kasana et al. 2008). Halos were measured for subsequent selection of cellulolytic microorganisms with a high potential for hydrolysis activity. The enzymatic activity index (IE) was calculated according to Hankin and Anagnostakis (1975).

\section{ENZYME ACTIVITY IN SUBMERGED CULTURES}

Isolates with cellulase activity in solid medium at all tested temperatures were cultured in a submerged culture. Conical flasks containing $50 \mathrm{~mL}$ of broth medium (Ramachandra et al. 1987) supplemented with CMC $0.5 \%(\mathrm{~m} / \mathrm{v})$ were inoculated with $10 \%$ of an inoculum culture of each isolate $\left(10^{8}\right.$ cells $\mathrm{mL}^{-}$ ${ }^{1}$, OD 0.5, $\left.570 \mathrm{~nm}\right)$, and incubated under agitation at $150 \mathrm{rpm}$ at 50,60 , and $70^{\circ} \mathrm{C}$ for 12 hours. Enzymatic activity was determined every two hours. The culture was centrifuged at $13.000 \mathrm{x}$ g for $15 \mathrm{~min}$ to separate the cells and the supernatant was considered the enzyme crude extract. A glucose standard curve was established to determine reducing sugar concentrations, according to Nelson (1944) and Somogy (1952). One unit of enzymatic activity (UEA) was considered the unit of enzymatic activity equivalent to the release of $1 \mu \mathrm{mol}$ glucose $\mathrm{mL}^{-1} \mathrm{~min}^{-1}$. All assays were performed in triplicate.
ENZYME ACTIVITY IN THE PRESENCE OF DIFFERENT SUBSTRATES IN SUBMERGED CULTURE

The strain that showed the best result in liquid medium was evaluated for the production of cellulase using different sources of cellulose substrate, such as CMC, microcrystalline cellulose, crushed rice husk and wheat straw. The flasks containing the liquid culture medium $(50 \mathrm{~mL})$ supplemented with $0.5 \%$ of different cellulose substrate as carbon source were incubated under agitation at $150 \mathrm{rpm}$ at $50^{\circ} \mathrm{C}$ for 12 hours. Every two hours, we determined the numbers of viable cells and endospores, as well as $\mathrm{pH}$ values and enzyme activity. All assays were performed in triplicate.

\section{ENZYME PURIFICATION}

For enzyme purification, the supernatant was saturated overnight with ammonium sulphate at $60-80 \%$, at a temperature of $4{ }^{\circ} \mathrm{C}$. Subsequently, the precipitate was collected by centrifugation at 10,000 $\mathrm{x} g$ for $10 \mathrm{~min}$ at $4^{\circ} \mathrm{C}$, resuspended in phosphate buffered saline (PBS) (pH 7.2), and kept at $4{ }^{\circ} \mathrm{C}$. The suspension was applied to a Sephadex G-100 gel filtration column $(2.5 \times 40 \mathrm{~cm})$, equilibrated with PBS buffer ( $\mathrm{pH} 7.2)$, and eluted in a gradient of $\mathrm{NaCl}\left(0-1 \mathrm{~mol} \mathrm{~L}^{-1}\right)$. Twenty fractions of $1.0 \mathrm{~mL}$ were collected and each fraction was submitted to an enzyme activity assay. The fractions with higher activities were mixed and kept for further assays.

\section{ACTIVITY AND THERMIC STABILITY OF CRUDE EXTRACT AT DIFFERENT PH VALUES}

The crude extract was submitted to enzymatic activity and thermic stability by incubating 2.0 $\mathrm{mL}$ of the extract in a water bath at $30,40,45,50$, $55,60,70$ and $80^{\circ} \mathrm{C}$ with buffer solutions $(0.2 \mathrm{M}$ $\mathrm{Na}_{2} \mathrm{HPO}_{4}+0.1 \mathrm{M} \mathrm{C}_{6} \mathrm{H}_{8} \mathrm{O}_{7}$ for $\mathrm{pH} 4-8 ; 0.1 \mathrm{M}$ Tris$\mathrm{HCl}$ for $\mathrm{pH} 9 ; 0.05 \mathrm{M} \mathrm{NaHCO}_{3}+0.1 \mathrm{M} \mathrm{NaOH}$ for $\mathrm{pH}$ 10). After $30 \mathrm{~min}$, an aliquot was collected for 
enzyme activity determination. Culture medium without inoculation was used as a control. The concentration of soluble protein was determined using the method describe by Bradford (1976).

\section{SODIUM DODECYL SULFATE POLYACRYLAMIDE GEL ELECTROPHORESIS (SDS-PAGE)}

The crude extract was analyzed by SDS-PAGE gel electrophoresis with 5\% staking gel and 12\% polyacrylamide. An aliquot of $35 \mu \mathrm{L}$ of the sample was heated at $100^{\circ} \mathrm{C}$ for $5 \mathrm{~min}$ and applied to the gel; electrophoresis was performed at $50 \mathrm{~mA}$ for 2 hours. The gel was stained with Coomassie Brilliant Blue G250 (Sigma-Aldrich) in methanolacetic acid-water (5:1:5, v/v). Decolorization was performed in $7 \%$ acetic acid.

\section{ISOLATE IDENTIFICATION}

Morphological and physiological tests were carried out according to Holt et al. (1994). Whole bacterial genomic DNA was extracted following the method described by Lin et al. (2010). The 16S rDNA gene was amplified using the primers 27F1 AGAGTTTGATCCTGCTCAG and 1494Rc TACGGCTACCTTGTTACGAC (Neilan et al. 1997). The reaction was performed at $1 \times$ reaction buffer, $0.2 \mathrm{mM}$ of each dNTP, $3 \mathrm{mM}$ of $\mathrm{MgCl}_{2}, 1.5$ U of Platinum ${ }^{\circledR}$ Taq DNA polymerase, $10 \mathrm{pmol}$ of each primer, $100 \mathrm{ng}$ of DNA, and ultrapure MilliQ water for a final reaction volume of $25 \mu \mathrm{L}$, in a Gene Amp PCR System 9700 thermocycler (Applied Biosystems). The PCR cycling conditions were as follows: initial denaturation at $95^{\circ} \mathrm{C}$ for 5 min, 30 cycles of denaturation at $94^{\circ} \mathrm{C}$ for 10 $\mathrm{s}$, annealing at $50^{\circ} \mathrm{C}$ for $20 \mathrm{~s}$, elongation at $72^{\circ} \mathrm{C}$ for $1 \mathrm{~min}$, final extension at $72^{\circ} \mathrm{C}$ for $7 \mathrm{~min}$. After the reaction, $1 \mu \mathrm{L}$ of amplified fragments was mixed with $2.0 \mu \mathrm{L}$ of loading buffer to verify integrity by electrophoresis in $1 \%$ agarose gel. The quantification of fragments was compared with Lambda DNA/EcoRI + HindIII DNA size standard (Promega) documented by the Kodak Gel Logic
212 system. Afterwards, the fragments were cloned into $\mathrm{pGEM}^{\circledR}$-T Easy Vector Systems cloning vector as recommended by the manufacturer. Escherichia coli DH5 $\alpha$ cells were transformed with the constructed clones (Sambrook et al. 1989). Sanger sequencing reaction was performed with BigDye XTerminator (GE Healthcare) using the vector primers M13 F/R and the internal primers $307 \mathrm{~F} / \mathrm{R}$, $704 \mathrm{~F} / \mathrm{R}$, and $1114 \mathrm{~F} / \mathrm{R}$ (modified by Lane 1991). Its products were inserted into an ABI PRISM $^{\circledR} 3100$ Genetic Analyzer capillary sequencer (Applied Biosystems). The quality of the reads generated was assessed using the software package Phred/ Phrap/Consed (Ewing et al. 1998, Ewing and Green 1998, Gordon et al. 1998). The consensus sequence obtained was compared with other sequences available in the GenBank/NCBI database using the BLAST tool (Altschul et al. 1997). The sequence has been deposited at GenBank/NCBI under the accession number MF099893.

\section{PHYLOGENETIC ANALYSES}

The nucleotide sequences obtained from the Sanger sequencing and the reference sequences retrieved from GenBank were aligned using CLUSTAL W (Thompson et al. 1994). All sequences were trimmed (sequence data matrix) and used to reconstruct phylogenetic trees. The $16 \mathrm{~S}$ rDNA gene phylogenetic trees were inferred using the maximum-likelihood (ML) reconstructed using the MEGA program package, version 7 (Kumar et al. 2016), using Kimura's two-parameter model of sequence evolution. The robustness of the phylogenetic tree was estimated via bootstrap analysis using 1,000 resamplings. The tree was visualized with FigTree 1.3.1 (http://tree.bio.ed.ac. uk/software/figtree).

\section{RESULTS}

Composting of organic waste, urban pruning, and sewage sludge allowed the isolation of 183 
bacterial isolates in the thermophilic phase. Among these, 22 were able to hydrolyze CMC on agar when incubated at $37^{\circ} \mathrm{C}, 15$ showed cellulolytic activity when incubated at $50^{\circ} \mathrm{C}$, seven performed cellulolytic activity when incubated at $60^{\circ} \mathrm{C}$, and three showed cellulolytic activity when incubated at $70^{\circ} \mathrm{C}$. Furthermore, the isolates that showed activity at $70^{\circ} \mathrm{C}$ were also able to hydrolyze CMC under all tested temperatures. Comparing the three isolates that presented the best profile for CMCase activity $(380,381$, and 382), we observed the largest halo produced by isolate 380 at all temperatures tested. Under incubation at $70^{\circ} \mathrm{C}$, isolate 380 , in contrast to isolates 381 and 382 , did not show activity reduction (Table I). Therefore, isolate 380 was selected for further enzymatic activity assays.

These isolates were collected at the end of the thermophilic phase of the composting process and at the beginning of the maturation phase, at an average temperature of $46^{\circ} \mathrm{C}$ (Heck et al. 2015). Thus, we selected the temperature of $50^{\circ} \mathrm{C}$ as the most suitable temperature for halo production in the solid cultures (Table I).

The three isolates showed enzymatic activity in submerged cultures supplemented with carboxymethyl cellulose at a range from 0.04 to 0.12 UEA mL $\mathrm{min}^{-1}$ (Table II). Activity peaks for each isolate started between four and six

TABLE I

Isolates producers of CMCase in solid medium supplemented by CMC 0.5\% (m/v) and hydrolysis halos (mm \pm SD*).

\begin{tabular}{|c|c|c|c|c|}
\hline \multicolumn{5}{|c|}{ Halo $(\mathrm{mm} \pm \mathrm{SD})$ for Temperatures of Incubation $\left({ }^{\circ} \mathrm{C}\right)$} \\
\hline ISOLATE & 37 & 50 & 60 & 70 \\
\hline 71 & $40 \pm 2.8$ & $35 \pm 3.5$ & - & - \\
\hline 72 & $35 \pm 3.5$ & $12.5 \pm 3.5$ & - & - \\
\hline 75 & $21 \pm 7.0$ & - & - & - \\
\hline 92 & $47 \pm 4.2$ & $39 \pm 6.3$ & $10 \pm 2.8$ & - \\
\hline 103 & $35 \pm 0$ & $20 \pm 1.4$ & - & - \\
\hline 104 & $35 \pm 5.6$ & $15 \pm 4.2$ & - & - \\
\hline 106 & $28 \pm 11.3$ & $4.0 \pm 0$ & - & - \\
\hline 135 & $28 \pm 2.8$ & - & - & - \\
\hline 148 & $52 \pm 2.8$ & $44.5 \pm 0.7$ & - & - \\
\hline 269 & $22 \pm 3.5$ & - & - & - \\
\hline 273 & $20 \pm 5.6$ & - & - & - \\
\hline 274 & $6.5 \pm 2.1$ & - & - & - \\
\hline 291 & $48 \pm 11.3$ & $12 \pm 2.8$ & - & - \\
\hline 297 & $19 \pm 6.3$ & - & - & - \\
\hline 302 & $46 \pm 0$ & $31 \pm 4.2$ & $15 \pm 5.0$ & - \\
\hline 347 & $45 \pm 2.1$ & - & - & - \\
\hline 351 & $30 \pm 5.6$ & $25 \pm 7.0$ & - & - \\
\hline 379 & $46 \pm 3.5$ & $59 \pm 5.0$ & $10 \pm 7.0$ & - \\
\hline 380 & $54 \pm 4.2$ & $60 \pm 2.8$ & $23.5 \pm 2.1$ & $20 \pm 2.8$ \\
\hline 381 & $47 \pm 2.8$ & $59 \pm 1.4$ & $26 \pm 1.4$ & $6.0 \pm 2.8$ \\
\hline 382 & $46 \pm 8.4$ & $37.5 \pm 2.1$ & $22 \pm 0$ & $14 \pm 3.5$ \\
\hline 387 & $52 \pm 4.2$ & $52 \pm 2.8$ & $26 \pm 1.4$ & - \\
\hline
\end{tabular}

*SD - Standard deviation. 
TABLE II

CMCase enzyme activity (UEA mL $\mathrm{min}^{-1}$ ) for isolates selected and cultured at $50^{\circ} \mathrm{C}$ in submerged culture supplemented with $0.5 \%$ of $\mathrm{CMC}$.

\begin{tabular}{|c|c|c|c|}
\hline Time of incubation & 380 & 381 & 382 \\
\hline $2 \mathrm{~h}$ & $0.04 \pm 0.008$ & $0.06 \pm 0.02$ & $0.06 \pm 0.04$ \\
\hline $4 \mathrm{~h}$ & $0.06 \pm 0.01$ & $0.06 \pm 0.02$ & $0.08 \pm 0.01$ \\
\hline $6 \mathrm{~h}$ & $0.12 \pm 0.008$ & $0.08 \pm 0.01$ & $0.08 \pm 0.01$ \\
\hline $8 \mathrm{~h}$ & $0.08 \pm 0.02$ & $0.08 \pm 0.01$ & $0.08 \pm 0.008$ \\
\hline $10 \mathrm{~h}$ & $0.08 \pm 0.03$ & $0.08 \pm 0.01$ & $0.06 \pm 0.01$ \\
\hline $12 \mathrm{~h}$ & $0.06 \pm 0.01$ & $0.06 \pm 0.02$ & $0.06 \pm 0.01$ \\
\hline $24 \mathrm{~h}$ & $0.06 \pm 0.01$ & $0.04 \pm 0.02$ & $0.04 \pm 0.009$ \\
\hline
\end{tabular}

TABLE III

Enzyme activity (UEA mL $\mathrm{min}^{-1}$ ) for isolate 380 under submerged culture supplemented with carboxymethyl cellulose (CMC), microcrystalline cellulose (MMC), rice husk and wheat straw, at $50^{\circ} \mathrm{C}$ of incubation.

\begin{tabular}{ccccc}
\hline Time of Incubation & CMC & MCC & Rice husk & Wheat straw \\
\hline 2h & $0.04 \pm 0.004$ & $0.006 \pm 0.015$ & $0.04 \pm 0.021$ & $0.04 \pm 0.021$ \\
$4 \mathrm{~h}$ & $0.06 \pm 0.141$ & $0.04 \pm 0.017$ & $0.04 \pm 0.021$ & $0.02 \pm 0.018$ \\
$6 \mathrm{~h}$ & $0.12 \pm 0.051$ & $0.008 \pm 0.020$ & $0.02 \pm 0.011$ & $0.02 \pm 0.014$ \\
$8 \mathrm{~h}$ & $0.04 \pm 0.0141$ & $0.003 \pm 0.0134$ & $0.02 \pm 0.013$ & $0.06 \pm 0.018$ \\
$10 \mathrm{~h}$ & $0.08 \pm 0113$ & $0.003 \pm 0.010$ & $0.06 \pm 0.014$ & $0.06 \pm 0.014$ \\
$12 \mathrm{~h}$ & $0.06 \pm 0.042$ & $0.016 \pm 0.0171$ & $0.06 \pm 0.008$ & $0.06 \pm 0.015$ \\
\hline
\end{tabular}

hours of incubation. Isolate 380 showed a higher performance than the other isolates during the 24 hours of the assay; the best results were obtained at 6 hours of cultivation (Table II).

Assays in submerged culture were performed with isolate 380 to test different cellulose sources: carboxymethyl cellulose, microcrystalline cellulose (MCC), rice husk and wheat straw (Table III), at an incubation temperature of $50^{\circ} \mathrm{C}$. The $\mathrm{CMC}$ showed the best induction of enzyme production compared to the other substrates. Isolate 380 showed a higher activity at 6 hours of incubation under CMC substrate, performing an enzyme production of 0.12 UEA $\mathrm{mL}^{-1} \mathrm{~min}^{-1}\left(0.02 \mathrm{mg}\right.$ glucose $\mathrm{mL}^{-1} \mathrm{~min}^{-}$ $\left.{ }^{1}\right)$, followed by wheat straw and rice husk, with the production of $0.06 \mathrm{UEA} \mathrm{mL} \mathrm{min}^{-1}(0.01 \mathrm{mg}$ glucose $\mathrm{mL}^{-1} \mathrm{~min}^{-1}$ ) at 8 and 10 hours of incubation, respectively. The microcrystalline cellulose substrate provided the lowest enzyme performance (0.04 UEA $\left.\mathrm{mL}^{-1} \mathrm{~min}^{-1}\right)$.
The precipitation of the CMC culture supernatant by ammonium sulfate at $60 \%$ and the enzyme purification by gelfiltration chromatography allowed the capture of 20 fractions. Out of that, three fractions showed the highest enzyme activity and were submitted to further assays.

A temperature range from 30 to $80^{\circ} \mathrm{C}$ was used to evaluate the thermic stability of the crude extract and the purified enzyme (Fig. 1). Enzyme activity was high at temperature above $50^{\circ} \mathrm{C}$ for both samples, and a significant activity occurred to $60^{\circ} \mathrm{C}$, with a result of $0.14 \mathrm{UAE} \mathrm{mL}^{-1} \mathrm{~min}^{-1}$ activity for crude extract and $0.12 \mathrm{UEA} \mathrm{mL}^{-1} \mathrm{~min}^{-1}$ for purified enzyme. These results confirm the thermophilic enzyme activity profile of the cellulolytic isolate 380.

Enzyme activity evaluation of the crude extract, at $\mathrm{pH}$ values ranging from 4.0 to 10.0 , was performed. After $30 \mathrm{~min}$, the activity was determined and compared to the result obtained 


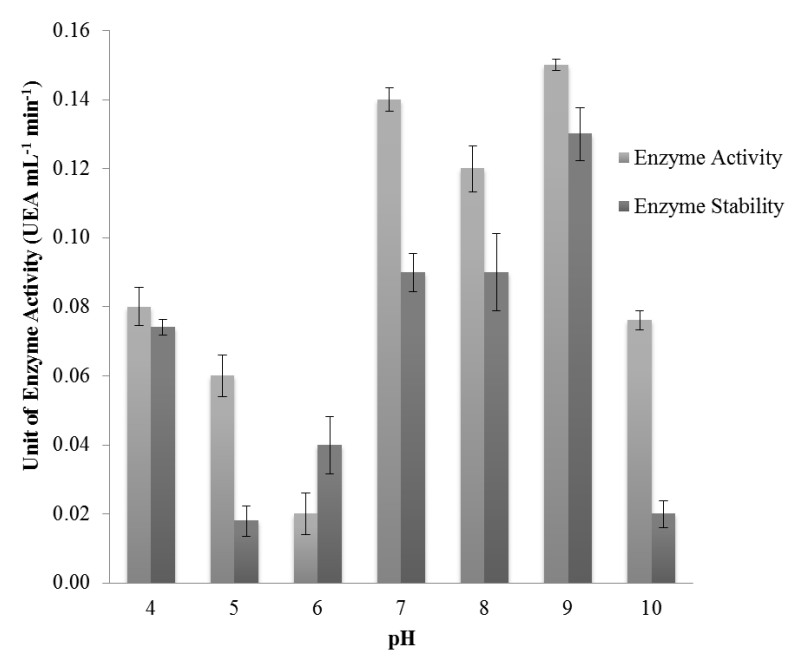

Figure 1 - Evaluation of crude extract and purified CMCase activity face to a temperature range of $30-80^{\circ} \mathrm{C}$ after 30 minutes of incubation.

previously by exposition of the crude extract to $\mathrm{pH}$ variation. Highest activity was measured at $\mathrm{pH}$ 7.0-9.0 (Fig. 2), and more than $60 \%$ of the enzyme activity was kept at higher $\mathrm{pH}$ range. Furthermore, at $\mathrm{pH} 9.0,87 \%$ of enzyme activity was kept after the period of incubation tested.

Isolate 380 showed a single band in a SDSPAGE with a molecular weight of approximately $20 \mathrm{kDa}$ for both crude extract and purified enzyme (Fig. 3). This isolate was a Gram-positive, aerobic, endospore-producing bacterium. The multiple alignments of the nucleotide $16 \mathrm{~S}$ rDNA sequence (nucleotide length 1,515 ) by ClustalW showed a high identity (99.7\%) with other Bacillus licheniformis sequences from NCBI (Fig. 4).

\section{DISCUSSION}

Isolate 380 could be identified as Bacillus licheniformis (Fig. 4). It was grouped in a clade (86\% bootstrap) with $B$. licheniformis SSCL 10 strain identified as a high chitinase producer $(2.4$ $\mathrm{U} \mathrm{mL}^{-1}$ ) (Abirami et al. 2016) and four other published $B$. licheniformis 16SrDNA sequences from GenBank. Various species of Bacillus presented relevant results related to cellulase production (Christakopoulos et al. 1999, Shabeb et al. 2010, Kim et al. 2012, Ladeira et al. 2015, Gaur and Tiwari 2015). In this study, we observed hydrolysis zones of up to $60 \mathrm{~mm}$ when the isolate was cultured at $50^{\circ} \mathrm{C}$ and above $45 \mathrm{~mm}$ at $37^{\circ} \mathrm{C}$. Moreover, isolates from the compost showed cellulolytic potential at $50^{\circ} \mathrm{C}$, with halos ranging from 19 to $21 \mathrm{~mm}$ (Chang et al. 2009). Similar results were achieved with our isolates, showing a promising potential for cellulase production.

Carboxymethyl cellulose is a soluble substrate and easily hydrolyzed. In this work, isolate 380 showed an enzyme activity of 0.12 UEA after 6 hours of incubation. A study involving the influence of temperature on enzyme activity showed variations in the production, with 0.001 $\mathrm{mg} \mathrm{mL} \mathrm{L}^{-1}$ of the enzyme at $50^{\circ} \mathrm{C}$ for a production of $344 \mathrm{mg} \mathrm{mL}^{-1}$ at $45^{\circ} \mathrm{C}$ (Shabeb et al. 2010). This result leads us to infer that isolate 380 may show an excellent production of cellulase at low and high temperatures, a crucial factor for its inoculation along the composting process, degrading cellulose sources in mesophilic and thermophilic phases. Furthermore, the hydrolysis of microcrystalline cellulose, for example, requires the synergistic action of different cellulases, which leads to the production of various enzymes.

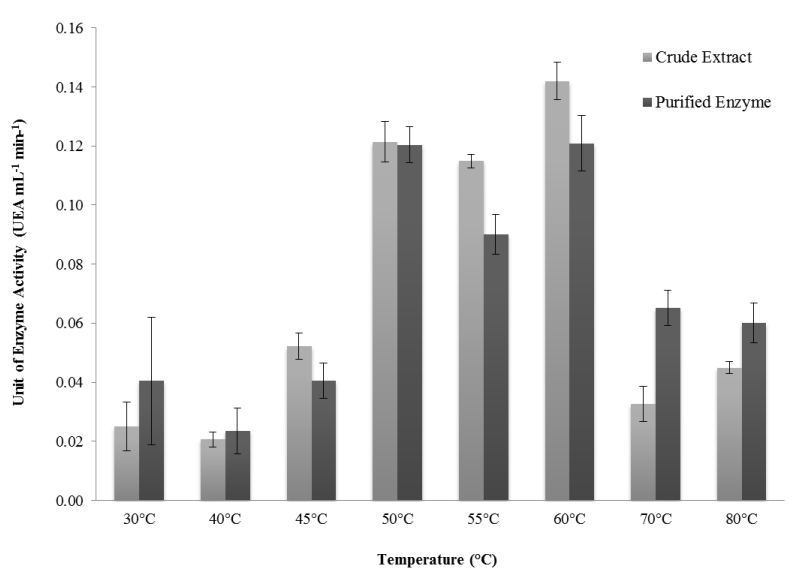

Figure 2 - Evaluation of activity and stability for CMCase crude extract face to $\mathrm{pH}$ range of 4.0-10.0. Assay performed after 30 minutes of incubation at $60^{\circ} \mathrm{C}$. 


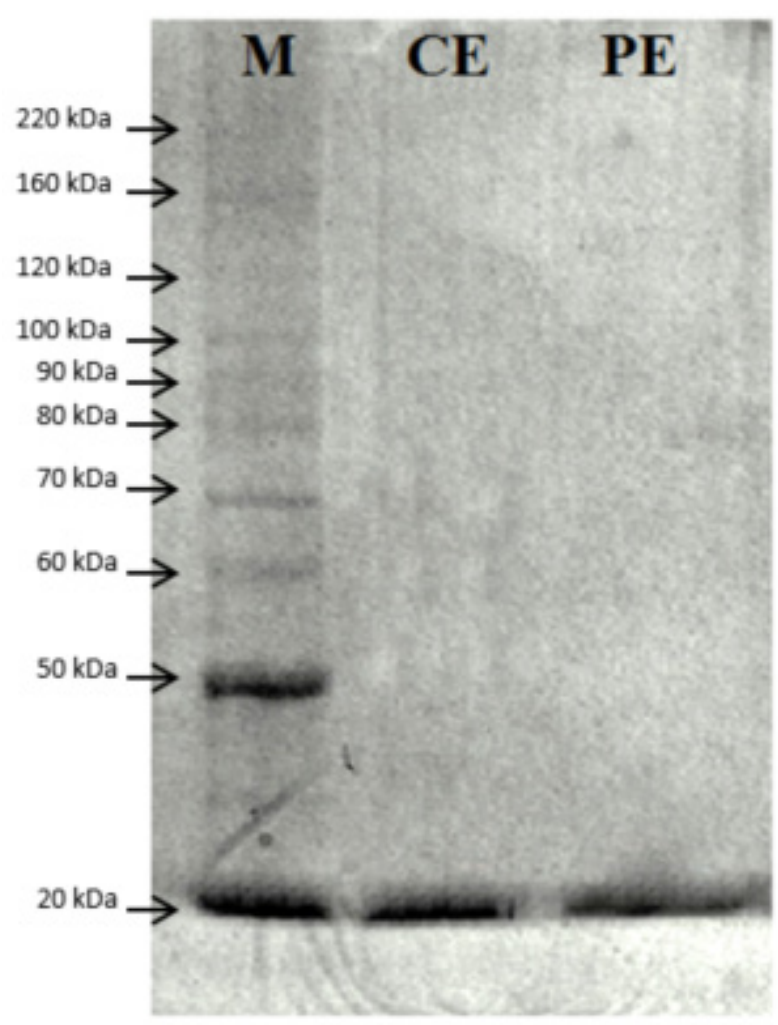

Figure 3 - The molecular weight of crude extract and purified CMCase in SDS-PAGE gel. Staining with Commasie Blue. M: Marker of 20-220 kDa range. CE- crude extract; PE- purified enzyme.

Also, its crystallinity has a significant influence on this process. Rice husk and wheat straw are lignified and more recalcitrant substrates, and the use of chemical treatments not always improves hydrolysis. Fungi usually hydrolyze wheat straw; however, to achieve complete hydrolysis, heat and mechanical treatments can be used (Gessesse and Mamo 1999, Gyalai-Korpos et al. 2010).

A few studies report the production of cellulases by the genus Bacillus under microcrystalline cellulose (Kim and Kim 1995, Waeonukul and Ratanakhanokchai 2007). Its hydrolysis needs the synergistic activity of different cellulases, such as endoglucanases and exoglucanases (Bhat and Bhat 1997, Lynd et al. 2002). Thus, the low activity for microcrystalline cellulose substrates may be linked to an impeded enzyme access to the substrate due to the high degree of crystallinity. The interaction

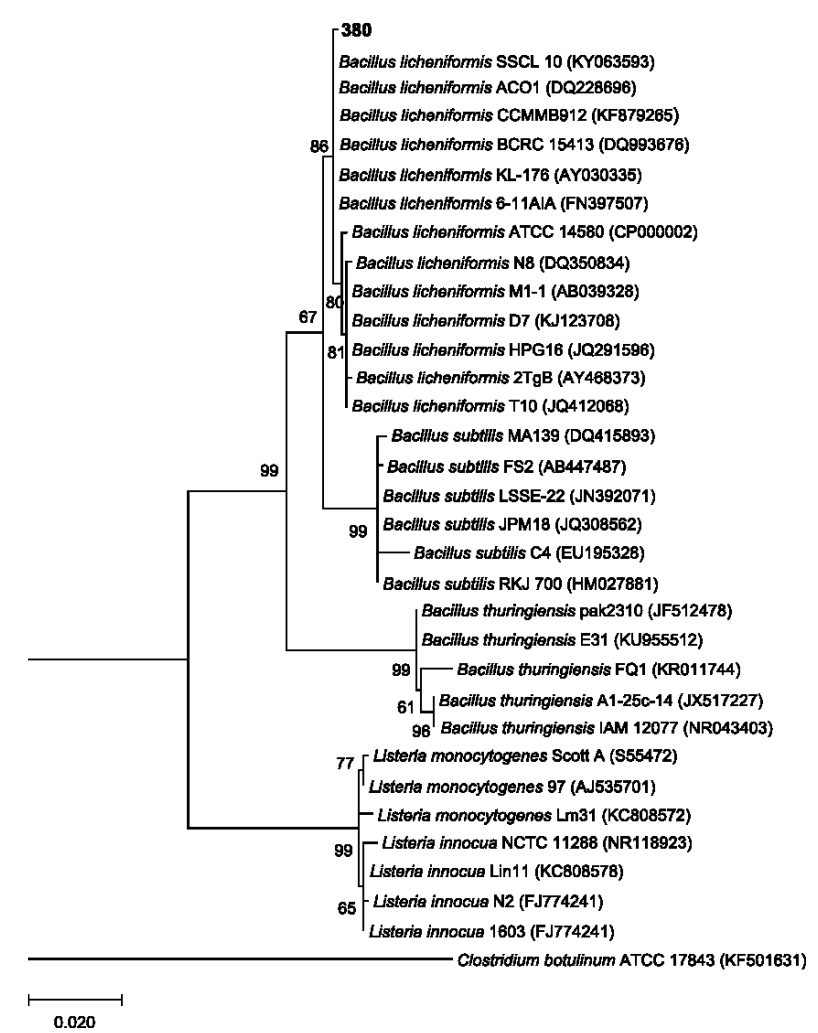

Figure 4 - Maximum likelihood phylogenetic tree based on $16 \mathrm{~S}$ rRNA gene sequences. The studied isolate is shown in bold. Bootstrap with 1000 resamplings was performed and values greater than $50 \%$ shown in nodes.

between different cellulases may promote higher hydrolase rates, which explains the synergistic between them (Kim and Kim 1992). The results show that the substrate carboxymethyl cellulose is more suitable for enzyme production under laboratory conditions.

The quantification of total proteins was performed in each step for purification, according to Bradford (1976). Precipitated crude extract and purified enzymes were evaluated. Our results for crude extract and purified enzyme activity (0.14 UEA $\mathrm{mL}^{-1} \mathrm{~min}^{-1}$ ) were similar to the findings of Chang et al. (2009) for isolates of the genus Bacillus. Rastogi et al. (2010) obtained 0.12 UEA $\mathrm{mL}^{-1}$ for crude extract CMCase for Bacillus sp. isolated from compost. Previous studies on purified enzyme stability at different temperature ranges have shown similar results (Bischoff et al. 2006, Li 
et al. 2008, Korpole et al. 2011). Previous studies observed enzyme activities ranging from $0.1 \mathrm{mg}$ $\mathrm{mL}^{-1}$ (Heck et al. 2002) to $6,000 \mathrm{mg} \mathrm{mL}^{-1}$ (Yin et al. 2010).

The crude extract assays in this work revealed good stability and enzyme activity (87\%) within a $\mathrm{pH}$ range from 7.0 to 9.0. Endoglucanases were described for the genus Bacillus with activity at $\mathrm{pH}$ values from 8.5 to 10.0 (Hakamada et al. 1997, Endo et al. 2001, Aygan et al. 2011). The CMCase activity response of $1.7 \mathrm{UEA} \mathrm{mL}^{-1}$ at $60^{\circ} \mathrm{C}$ and $\mathrm{pH}$ 8.0 was obtained by Singh et al. (2004). Several studies report that enzyme activity remains at $100 \%$ after a few hours of incubation, but increasing activity by exposure to high temperatures for a few hours is rarely reported; usually, there is a tendency to decreased enzyme activity with longer exposure. Similar to our work, Christakopoulos et al. (1999) evaluated purified endoglucanase from Bacillus pumilus, showing $90 \%$ of enzyme activity at $60^{\circ} \mathrm{C}$. The enzymes undergo the same structural effects as globular proteins in terms of temperature and $\mathrm{pH}$ variation. Extreme $\mathrm{pH}$ oscillation may change the enzymatic structure due to charge repulsion, while mild changes may induce enzyme dissociation, sometimes leading to more active species or to complete inactivation (Lehninger et al. 2004).

The SDS-PAGE revealed that the $20 \mathrm{kDa}$ bands resulted of crude extract and partially purified enzyme assays for isolate 380 . The molecular weight of purified and partially purified cellulases varies largely, from 6 to $80 \mathrm{kDa}$ (Kim et al. 2005, 2009, Gaur and Tiwari 2015). Low molecular weight enzymes, formed by one polypeptide chain and with a disulfide bond, and are generally more stable to heat than oligomeric enzymes with high molecular weight (Furigo and Pereira 2001).

Some microorganisms, such as cellulolytic fungi, show high hydrolysis activity at acidic conditions. Bacteria with cellulase activity are of interest in composting processes with high concentrations of lignocellulosic compounds, thereby reducing the time required to reach the maturation phase. In composting processes, the thermophilic phase is characterized by alkalinization due to the volatilization of nitrogen compounds (Heck et al. 2013), which facilitates alkalophilic enzyme activity. Studies with Bacillus sp. isolates evaluated the benefits of microbial additives in agricultural fertilizers and edible mushroom production for the genus Agaricus sp. (Figueiredo et al. 2013, Ribeiro et al. 2017). Bacterial cellulase activity facilitates the predegradation of lignocellulosic sources, favoring the colonization by secondary decomposers and thus improving substrate use and economic viability of mushroom culture (Dias 2010, Figueiredo et al. 2013).

Enzymes produced by thermophilic bacteria have attracted attention of industrial segment devices due to their high activity and stability at high temperatures, mainly using agro-industrial wastes as substrates for Bacillus sp. cellulase producers (Heck et al. 2002, Shabeb et al. 2010). In the composting process, lignocellulosic and recalcitrant compounds are first hydrolyzed by fungi and actinobacteria (Gyalai-Korpos et al. 2010, Pierre et al. 2011). Some studies on industrial cellulase production by Bacillus strains are currently being developed due to the high bacterial growth, compared to fungi, and the ability to adapt to low-cost carbon sources, such as sugar cane bagasse. Moreover, bacterial cellulase is a potent enzyme for the application in second generation ethanol produced from sugarcane biomass in Brazil (Acharya and Chaudhary 2012, Ladeira et al. 2015).

\section{CONCLUSIONS}

Bacillus licheniformis 380, isolated during composting, was capable of producing alkalophilic CMCase at a relatively high temperature $\left(50^{\circ} \mathrm{C}\right)$ in the presence of different substrates. These cellulases may have potential application in biotechnology 
industries, as well as bioaugmentation processes, accelerating the degradation of organic matter, especially in edible mushroom culture, degrading cellulosic wastes during primary degradation phase. Further studies evaluating adequate implementation are needed.

\section{ACKNOWLEDGMENTS}

The authors thank Professor Adriano Brandelli, Department of Food Science / Universidade Federal do Rio Grande do Sul, for help with enzyme purification techniques, and Professor Marli Fiore, Center for Nuclear Energy in Agriculture / Universidade de São Paulo, for molecular analyzes tools.

\section{REFERENCES}

ABIRAMI S, YOGALSAKSHMI K, PUSHPA ASR AND KANANAN M. 2016. Screening and identification of chitin degrading bacteria from shrimp shell waste dumping soil environment and its media optimization for chitinase enzyme production. J Pharm Pharmac Sci 5: 743-757.

ACHARYA S AND CHAUDHARY A. 2012. Optimization of fermentation conditions for cellulases production by Bacillus licheniformis MVS21 and Bacillus sp. MVS3 isolated from Indian hot spring. Braz Arch Biol Techn 55: 497-503.

ALTSCHUL SF, MADDEN TL, SCHÄFFER AA, ZHANG J, ZHANG Z, MILLER W AND LIPMAN DJ. 1997. Gapped BLAST and PSI BLAST: a new generation of protein database search programs. Nucleic Acids Res 25: 33893402 .

AMORE A, PEPE O, VENTORINO V, BIROLO L, GIANGRANDE C AND FARACO V. 2013. Industrial waste based compost as a source of novel cellulolytic strains and enzymes. FEMS Microbiol Lett 339: 93-101.

AYGAN A, KARCIOGLU LAND ARIKAN B. 2011. Alkaline thermostable and halophilic endoglucanase from Bacillus licheniformis C108. Afr J Biotechnol 10: 789-796.

BÉGUIN P AND AUBERT JP. 1994. The biological degradation of cellulose. FEMS Microbiol Rev 13: 25-58.

BHAT MK. 2000. Cellulases and related enzymes in biotechnology. Biotechnol Adv 18: 355-383.

BHAT MK AND BHAT S. 1997. Cellulose degrading enzymes and their potential industrial applications. Biotechnol Adv 15: 583-620.

BISCHOFF KM, ROONEY AP, LI XL, LIU S AND HUGHES SR. 2006. Purification and characterization of a family 5 endoglucanase from a moderately thermophilic strain of Bacillus licheniformis. Biotechnol Lett 28: 1761-1765.

BRADFORD MM. 1976. A rapid and sensitive method for quantitation of microgram quantities of protein utilizing the principle of dye binding. Anal Biochem 72: 248-254.

CARVALHO MA, COSTA LMAS, SANTOS DMS, DIAS DR, ZIED DC AND DIAS ES. 2016. Ligninase and cellulase activity of Lentinula edodes (Berk.) Pegler strains in different culture media. J Pure Appl Microbiol 10: 1683-1691.

CHANG CC, NG CC, WANG CY AND SHYU YT. 2009. Activity of cellulase from Thermoactinomycetes and Bacillus spp. isolated from Brassica waste compost. Sci Agric 66: 304-308.

CHRISTAKOPOULOS P, HATZINIKOLAOU DG, FOUNTOUKIDIS G, KEKOS D, CLAEYSSENS M AND MACRIS BJ. 1999. Purification and mode of action of an alkali-resistant endo-1,4- $\beta$-glucanase from Bacillus pumilus. Arch Biochem Biophys 361: 61-66.

DIAS ES. 2010. Mushroom cultivation in Brazil: challenges and potential for growth. Review. Cienc Agrotec 34: 795-803.

ENDO K, HAKAMADA Y, TAKIZAWA S, KUBOTA H, SUMITOMO N, KOBAYASHI T AND ITO S. 2001. A novel alkaline endoglucanase from an alkaliphilic Bacillus isolated: enzymatic properties, and nucleotide and deduced amino acid sequences. Appl Microbiol Biot 57: 109-116.

EWING B AND GREEN P. 1998. Base-calling of automated sequencer traces using Phred. II, Error probabilities. Genome Res 8: 186 -194.

EWING B, HILLIER L, WENDL MC AND GREEN P. 1998. Base-calling of automated sequencer traces using phred. I. Accuracy assessment. Genome Research 8: 175-185.

FIGUEIRÊDO VR, MARTOS ET, SIQUEIRA FG, MACIEL WP, SILVA R, RINKER DL AND DIAS ES. 2013. Microbial inoculation during composting improves productivity of sun mushroom (Agaricus subrufescens Peck). Afr J Microbiol Res 7: 4430-4434.

FOSTER MH AND WHITEMAN GR. 1992. Bioaugmentation aids wastewater systems. Available at: http//www. bioaugmentation.com/article.html. Accessed 24 September 2016.

FURIGO AJ AND PEREIRA EB. 2001. Enzimas e suas aplicações: Cinética enzimática. Universidade Federal de Santa Catarina, Florianópolis, 39 p.

GAUR R AND TIWARI S. 2015. Isolation, production, purification and characterization of an organic-solventthermostable alkalophilic cellulase from Bacillus vallismortis RG-07. BMC Biotechnol 15: 1-12.

GESSESSE A AND MAMO G. 1999. High-level xylanase production by an alkaliphilic Bacillus sp. by using solidstate fermentation. Enzyme Microb Tech 25: 68-72. 
GORDON D, ABAJIAN C AND GREEN P. 1998. Consed: A graphical tool for sequence finishing. Genome Res 8: 195-202.

GYALAI-KORPOS M, NAGY G, MARECZKY Z, SCHUSTER A, RECZEY K AND SCHMOLL M. 2010. Relevance of the light signaling machinery for cellulase expression in Trichoderma reesei (Hypocrea jecorina). BMC Res Notes 3: 330-340.

HAKAMADA Y, KOIKE K, YOSHIMATSU T, MORI H, KOBAYASHI T AND ITO S. 1997. Thermostable alkaline cellulose from an alkaliphilic isolate, Bacillus sp., KSM-S238. Extremophiles 1: 151-156.

HANKIN L AND ANAGNOSTAKIS SL. 1975. The use of solid media for detection of enzymes production by fungi. Mycologia 67: 597-607.

HECK JX, HERTZ PF AND AYUB MAZ. 2002. Cellulase and xylanase productions by isolated amazon Bacillus strains using soybean industrial residue based solid-state cultivation. Braz J Microbiol 33: 213-218.

HECK K, DE MARCO EG, DUARTE MW, SALAMONI SP AND VAN DER SAND ST. 2015. Pattern of multiresistant to antimicrobials and heavy metal tolerance in bacteria isolated from sewage sludge samples from a composting process at a recycling plant in southern Brazil. Environ Monit Assess 187: 1-11.

HECK K, DE MARCO EG, HAHN ABB, KLUGE M, SPILKI FR AND VAN DER SAND ST. 2013. Evaluation of degradation temperature of compounds in a composting process and microbiological quality of the compost. Rev Bras Eng Agr Amb 17: 54-59.

HOLT J, KRIEG NR AND SNEATH PHA. 1994. Bergey's Manual of Systematic Bacteriology. $9^{\text {th }}$ ed., Baltimore: Williams \& Wilkins.

KASANA RC, SALWAN R, DHAR H, DUTT S AND GULATI A. 2008. A rapid and easy method for the detection of microbial cellulases on agar plates using Gram's iodine. Curr Microbiol 57: 503-507.

KIM DS AND KIM CH. 1992. Production and characterization of crystalline cellulose-degrading cellulase components from a thermophilic and moderately alkalophilic bacterium. J Microbiol Biotechn 2: 7-13.

KIM CH AND KIM DS. 1995. Purification and specifity of a specific endo- $\beta$-1,4-D-glucanase (Avicelase II) resembling exo-cellobio hydrolase from Bacillus circulans. Enzyme Microb Tech 17: 248-254.

KIM J, HUR S AND HONG J. 2005. Purification and characterization of an alkaline cellulase from a newly isolated alkalophilic Bacillus sp. HSH-810. Biotechnol Lett 27: 313-316.

KIM B, LEE B, LEE Y, JIN I, CHUNG C AND LEE J. 2009. Purification and characterization of carboxymethyl cellulase isolated from a marine bacterium, Bacillus subtilis subsp. subtilis A-53. Enzyme Microb Tech 44: 411-416.

KIM YK, LEE SC, CHO YY, OH HJ AND KO YH. 2012. Isolation of cellulolytic Bacillus subtilis strains from agricultural environments. ISRN Microbiol 2012: 1-9.

KINET R, DESTAIN J, HILIGSMANN S, THONART P, DELHALLE L, TAMINIAU B, DAUBE G AND DELVIGNE F. 2015. Thermophilic and cellulolytic consortium isolated from composting plants improves anaerobic digestion of cellulosic biomass: Toward a microbial resource management approach. Bioresource Technol 189: 138-144

KORPOLE S, SHARMA R AND VERMA D. 2011. Characterization and phylogenetic diversity of carboxymethyl cellulase producing Bacillus species from a landfill ecosystem. Indian J Microbiol 51: 531-535.

KUMAR S, STECHER G AND TAMURA K. 2016. MEGA7: Molecular Evolutionary Genetics Analysis Version 7.0 for Bigger Datasets. Mol Biol Evol 33: 1870-1874.

LANE DJ. 1991. 16S/23S rRNA sequencing. In: Stackebrandt E and Goodfellwon M (Eds), Nucleic acid techniques in bacterial systematics. Chichester: J Wiley \& Sons, p. 115-175.

LADEIRA SA, CRUZ E, DELATORRE AB, BARBOSA JB AND MARTINS MLL. 2015. Cellulase production by thermophilic Bacillus sp. SMIA-2 and its detergent compatibility. Eletron J Biotechn 18: 110-115.

LEHNINGER AL, NELSON DL AND COX MM. 2004. Lehninger's Principles of Biochemistry, W.H. Freeman, New York, NY, USA, $4^{\text {th }}$ ed.

LI W, ZHANG WW, YANG MM AND CHEN YL. 2008. Cloning of the thermostable cellulase gene from newly isolated Bacillus subtilis and its expression in Escherichia coli. Mol Biotechnol 40: 195-201.

LIN S, WU Z, YU G, ZHU M, YU B AND LI R. 2010. Genetic diversity and molecular phylogeny of Planktothrix (Oscillatorailes, cyanobacteria) strains from China. Harmful Algae 9: 87-97.

LÓPEZ-GONZÁLEZ JA, VARGAS-GARCÍA MC, LÓPEZ MJ, ESTRELLA FS, JURADO M AND MORENO J. 2014. Enzymatic characterization of microbial isolates from lignocellulose waste composting: Chronological evolution. J Environ Manage 145: 137-146.

LYND LR, WEIMER PJ, ZYL WHV AND PRETORIUS IS. 2002. Microbial cellulose utilization: fundamentals and biotechnology. Microbiol Mol Biol Rev 66: 506-577.

MARTIN-RYALS A, SCHIDEMAN L, LI P, WILKINSON H AND WAGNER R. 2015. Improving anaerobic digestion of a cellulosic waste via routine bioaugmentation with cellulolytic microorganisms. Bioresour Technol 189: 62-70.

NEILAN BA, JACOBS D, DEL DOT T, BLACKALL LL, HAWKINS PR, COX PT AND GOODMAN AE. 1997. rRNA sequences and evolutionary relationships among 
toxic and nontoxic cyanobacteria of the genus Microcystis. Int J Syst Bacteriol 47: 693-697.

NELSON N. 1944. A photometric adaptation of Somogy method for the determination of glucose. J Biol Chem 153: 375-380.

PALMISANO AC AND BARLAZ MA. 1996. Microbiology of solid waste. Boca Raton: CRC Press.

PIERRE G, MAACHE-REZZOUG Z, SANNIER F AND REZZOUG SA. 2011. High-performance hydrolysis of wheat straw using cellulose and thermomechanical pretreatment. Process Biochem 46: 2194-2200.

RABONOVICH ML, MELNIK MS AND BOLOBOBA AV. 2002. Microbial Cellulases (Review). Appl Biochem Microbiol 38: 305-322.

RAMACHANDRA M, CRAWFORD DL AND POMETTO AL. 1987. Extracellular enzyme activities during lignocellulose degradation by Streptomyces sp. a comparative study of wild-type and genetically manipulated strains. Appl Environ Microbiol 53: 27542760.

RASTOGI G, BHALLA A, ADHIKARI A, BISCHOFF KM, HUGHES SR, CHRISTOPHER LP AND SANI RK. 2010. Characterization of thermostable cellulases produced by Bacillus and Geobacillus strains. Bioresource Technol 101: 8798-8806.

RIBEIRO NQ, SOUZA TP, COSTA LMAS, CASTRO CP AND DIAS ES. 2017. Microbial additives in the composting process. Cien Agrotec 41: 159-168.

SAMBROOK J, FRITSCH EF AND MANIATIS T. 1989. Molecular Cloning: A Laboratory Manual, $2^{\text {nd }}$ ed., Cold
Spring Harbor Laboratory Press, Cold Spring Harbor, NY.

SÁNCHEZ-MONEDERO MA, ROIG A, PAREDES C AND BERNAL MP. 2001. Nitrogen transformation during organic waste composting by the Rutgers system and its effects on $\mathrm{pH}, \mathrm{EC}$ and maturity of the composting mixtures. Bioresour Technol 78: 301-308.

SHABEB MSA, YOUNIS MAM, HEZAYEN FF AND NOUR-ELDEIN MA. 2010. Production of cellulose in low-cost medium by Bacillus subtilis KO strain. World Appl Sci J 8: 35-42.

SINGH J, BATRA N AND SOBTI RC. 2004. Purification and characterization of alkaline cellulase produced by a novel isolated, Bacillus sphaericus JS1.J Ind Microbiol Biot 31: 51-56.

SOMOGY M. 1952. Notes on sugar determination. J Biol Chem 195:19-23.

THOMPSON JD, HIGGINS DG AND GIBSON TJ. 1994. CLUSTAL W: improving the sensitivity of progressive multiple sequence alignment through sequence weighting, position-specific gap penalties and weight matrix choice. Nucleic Acids Res 22: 4673-4680.

WAEONUKUL R AND RATANAKHANOKCHAI K. 2007. Multiple cellulases and cyanoses from Bacillus circulans and B6 during growth on avicel under an aerobic condition. Thai J Biotechnol 131: 362-369.

YIN LJ, LIN HH AND XIAO ZR. 2010. Purification and characterization of a cellulase from Bacillus subtilis YJ1. J Mar Sci Technol 18: 466-471. 